\title{
How quality affects the bottom line?: A literature review
}

\author{
J oaquín Texeira-Quirós ${ }^{1}$, J osé A. Almaça ${ }^{2}$, Maria do Rosário Fernandes-J ustino ${ }^{1}$ \\ ${ }^{1}$ University of Extremadura (Spain), ${ }^{2}$ University Autonoma of Lisbon (Portugal) \\ jtexeira@unex.es, jalmaca@universidade-autonoma.pt, mariarjustino@gmail.com
}

Received March, 2009

Accepted September, 2010

\begin{abstract}
:
Improving quality is one of the tools that companies have to improve or maintain their market position. However, despite the large number of papers published, a clear conclusion of the impact of ISO9000 standards on business results has yet to be reached, given there are many conflicting opinions. Thus, the aim of this paper is to review the literature on some of the many published research papers, seeking some way to analyse the existing relationship between the implementation of systems of quality management, ISO9000 certification, quality costs, results, and their effect on company performance.
\end{abstract}

Keywords: quality, ISO9000, Performance, TQM.

JEL Codes: L15, L25

\section{Introduction}

The Total Quality philosophy has been evolving since its appearance in the early $20^{\text {th, }}$ century as companies feel the need to increase their level of competitiveness within the market in order to secure their continuity. This has been driven by increasingly global markets which in turn bring greater competences into the 


\section{- Intangible Capital}

Intangible Capital, 2010 - 6(2):258-271 - ISSN: 1697-9818

doi:10.3926/ic.2010.v6n2.p258-271

entrepreneurial environment and an increasing number of customers demanding higher quality products.

In today's global market, where dealings with international customers and suppliers are the norm, it is not enough for companies simply to launch products or services of high quality on the market. They must ensure that these meet standards and requirements that assure clients of their reliability. This sophisticated demand has led to our reflection on the importance of implementing a management system that is entirely quality oriented, i.e. a total quality management system. Customers are now much better informed and are increasingly demanding. They confirm whether a product of a particular brand is certified so as to ensure its quality.

Due to its growing widespread acceptance, ISO9000 is becoming an important factor in international trade, almost an imperative for companies that export to the European Union (EU) where buyers often explicitly request ISO9000 certification (Erel \& Ghosh, 1997).

Currently, the ISO9000 certification is the primary unit of measurement and proof of quality internationally, and in this sense to implement a quality system presents itself as an excellent support of the same and ISO9000 certification as its flag (Escanciano, 2002).

Therefore, in 1987 the International Organization for Standardization (ISO) based in Geneva published a harmonized set of standards ensuring quality, known as ISO9000, and a large number of companies around the world have introduced the basics of quality management. Accordingly, and in line with the ISO Survey 2008, the total number of ISO 9001 certificates issued worldwide was 982832 in 176 countries, representing an increase of 31346 certificates, 3\% more than the previous year. China currently has the largest number of certified companies. Curiously, American companies do not seem to be as interested in obtaining ISO certifications as European competitors do; Italy, Spain, Japan, Germany and even England and India have more certifications than the USA. Nevertheless, it should be noted that the USA, together with Japan, was a pioneer in the application of total quality management and it focuses more on this system than on the ISO standards created in Europe due to its history in terms of quality management (Sun, 1999). 


\section{Intangible Capital}

Intangible Capital, 2010 - 6(2):258-271 - ISSN: 1697-9818 doi: 10.3926/ic.2010.v6n2.p258-271

In recent years, alongside the growing interest expressed by many firms in the ISO9000 family of standards, there has been an explosion of published works on various issues associated with ISO9000 registration (Ebrahimpour et al., 1997).

\section{Total Quality Management (TQM) and ISO9000}

The rapid expansion of ISO9000 certification as well as total quality management, reflects a strong interest in academic literature. However, though the total quality management and ISO9000 do not oppose their basic principles, these two areas have been confused (Martínez-Costa \& Martínez-Lorente, 2004).

It is common to find some confusion in the literature between the implementation of ISO9000 and TQM as they have some points in common. However, the ISO9000 is a testament to others that the company follows general standardization procedures, while TQM is intended to be a management system that improves quality internally (Martinez-Costa \& Martínez-Lorente, 2004). One of the benefits attributable to the standard is that it constitutes a good first step towards a TQM system; creating consciousness about quality amongst workers and a good climate for its implementation (Sun, 2000; Escanciano et al., 2001).

There are several published works about the motivations of companies to be certified under the ISO9000 standard. According to Tsiotras and Gotzamani (1996), there are essentially four main reasons that explain why companies implement a total quality management and cost system: improving the company's image and reputation abroad, meeting foreign demand and market pressures, facilitating and simplifying procedures and contracts between the company and its customers, and ultimately increasing productivity and the company's internal control and existing systems of quality management that the company may have implemented.

There is a plethora of research articles describing implementation of ISO9000 quality systems and examining success stories (Heras et al., 2002). In this sense, there have been a number of studies conducted on the motivational factors of certification, its costs and benefits, and its effects on business performance (Askey \& Dale, 1994; Vloeberghs \& Bellens, 1996; Terziovki \& Samson, 1997; Ittner \& Larcker, 1997; Youngdahl \& Kellogg, 1997; Samson \& Terziovski, 1999; Sun, 1999; Casadesús \& Giménez, 2000; Lima et al., 2000; Yamada, 2001; Fuentes, 2002; Martínez-Lorente \& Martínez-Costa, 2004; Bhuiyan \& Alam, 2004; Corbett et al., 2005; Sansalvador \& Rubio, 2005; Molina et al., 2007; Benner \& Veloso, 2008; 


\section{- Intangible Capital}

Intangible Capital, 2010 - 6(2):258-271 - ISSN: 1697-9818 doi:10.3926/ic.2010.v6n2.p258-271

Feng et al., 2008, Texeira \& Justino, 2009; Martínez-Costa et al., 2009; Boiral \& Amara, 2009). Some authors show a positive relationship and some benefits (Ittner \& Larcker, 1997; Samson \& Terziovski, 1999; Casadesús \& Giménez, 2000; Heras et al., 2002; Martínez-Costa \& Martínez-Lorente, 2004; Naveh \& Marcus, 2005; Texeira e tal., 2009). Others have a less optimistic view of the benefits (Terziovski \& Samson, 1997; Sun, 1999; Corbett et al., 2005; Feng et al., 2008).

\section{Synthesis of published studies}

In 1997, Terziovski and Samson published one of the more rigorous studies analysing this subject, whose objective was to test the relationship between ISO 9000 certification and organizational performance in the presence and absence of a total quality management (TQM) environment. The analysis was performed on a sample of 962 industrial companies in Australia and 379 from New Zealand and found that the ISO9000 certification does not have a significantly positive organizational performance on its own. The authors say that the main motivation for companies to have a quality certification is the ability of certification to open doors to new customers that would be difficult to achieve without the quality certification. In this sense, Youngdahl and Kellogg (1997), examined the relationship between customer service, quality assurance, satisfaction and effort -all this in the perspective of the costs of quality-- and found that the classification of costs to quality customer service and their relationship with both satisfaction and effort, provides important capabilities to the design and implementation of services. Thus, the cost of quality concept predicts that as quality increases the total cost of quality decreases (Hendricks \& Singhal, 2001). The internal and managerial motivation to adopt ISO9000 often has a positive effect on the likelihood of a certified organization to achieve a better-performing effectiveness configuration (Boiral \& Amara, 2009).

Terziovski and Samson (1997) found that although ISO9000 had little or no impact on company performance, it can contribute to organizational performance if a climate of change is created. However, leadership, management of people, and customer focus were the strongest significant predictors of performance (Samson \& Terziovski, 1999). Similarly, Sun (1999) found that TQM practices such as quality leadership, human resource development, and quality information contributed to an increase in customer satisfaction and business performance. 
The time and cost of implementing TQM can vary across firms, the extent of potential gain from implementing TQM can be impacted by a firm's technology, and the synergies in implementing TQM can be dependent on the number of different markets in which a firm operates (Hendricks and Singhal, 2001). For this reason Ittner and Larcker (1997) analysed the consequences of the use and performance of strategic control strategies using data collected in a survey carried out by an international consulting firm and management (1991), covering the car industry and information technology in Canada, Germany, Japan and the USA. The results of this study indicate that the organizations with greater emphasis on quality tend to use more strategic control of quality related to these practices, highlighting the Japanese manufacturers. They noted that the strategic control practices are negatively associated with performance in line with claims that the systems of formal strategic control can actually harm performance in some circumstances. This conclusion is consistent with Samson and Terziovski (1999), argue that strategic planning and management process have no effect on operating performance.

In the automotive industry, several major manufacturers have imposed on their suppliers industries specific quality standards that incorporate ISO9000 requirements. Thus, the QS-9000 standard was developed and has been adopted by Ford, Chrysler, and General Motors, the AVSQ 94 standard by Fiat, the VDA 6 by Audi, BMW, Mercedes, and Volkswagen, and the EAQF 94 standard by Renault, Citroen, and Peugeot (Romano, 2000).

Benner and Veloso (2008) studied the automotive companies in the U.S., where they first explored how the expected performance benefits from the processes of management practices, such as ISO9000, can dilute while most companies in a given sector adopt them. Secondly, they explored the firm-specific conditions under which these practices might lead to sustainable performance advantages. The authors propose a possible explanation for the difference for those who adopt the standard before and those who adopt the rule later. The advantages on the financial performance of the pioneers tend to disappear as the late adopters implement similar improvement practices. The fact that this study has been carried out in the automotive industry, a sector which is constantly changing and that technology changes rapidly, has had an influence in this finding. If an organizational practice is firm-specific, valuable, and difficult to imitate, it may lead to a sustainable competitive advantage (Peteraf, 1993). 
It takes time for a company to reap the benefits from an ISO9000 quality management system and it is most unlikely to cause a swift reversal in a company's commercial or financial results (Heras et al., 2002). According to Casadesús and Gimenéz (2000), the ISO9000 certification process represents an evolution in how a company and quality system should be managed and it is the key to the success of business management. Consistent implementation of a quality management system contributes significantly to a better financial performance (Corbett et al., 2005). The way by which a company implements the standard and introduces the changes and distinguishes itself from the others in operating performance, that is, the better the company uses the standard daily acts as a catalyst for greater operational performance in the implementation of ISO9000 (Naveh \& Marcus, 2005).

The impact of total quality management (TQM) on the performance of 108 companies that began TQM implementation between 1981 and 1991 was measured by comparing each firms' performance to a control benchmark designed to capture what the performance would have been without TQM. The results indicate that performance, measured by both accounting variables and stock returns, is improved for the firms adopting TQM, and the improvement is consistently stronger for firms with more advanced TQM systems (Easton \& J arrel, 1998). Also, Molina et al. (2007), analyses the relationship between quality management and knowledge transfers, on a sample of 197 Spanish firms. The results confirm the importance of the different quality management practices on internal and external knowledge transfers. By the same token, Romano (2000) found that the impact of certification is clearest in the areas of quality (both internal and external quality and their related costs).

Casadesús and Giménez (2000) carried out an empirical study in 288 companies in the Autonomous Community of Catalonia, certified by ISO9000, determining the internal and external benefits obtained after certification. They conclude that $65 \%$ of the companies acquired internal and external benefits, while $15 \%$ had more modest benefits. For the authors, there is no doubt that the process of certification according to ISO9000, provides an evolution in how to manage a company, the organization, communication and quality system, in general are the key to success in business management. It takes a cultural change, which affects the whole organization, where continuous improvement has become a basic tool to advance business competitiveness. In line with this idea are Terziovski and Samson (1997), 
by claiming that ISO9000 can increase organizational performance and that the ISO itself created a climate of change.

In 1999, Sun published a study whose main objective was to make a comparative study of international practices in quality management in Norway, USA, China, India and Mexico. This study was based on research done as follows: the first version of the questionnaire is designed according to the U.S. Baldrige Quality Award Model by Toledo University with the purpose of frequency and comparability, all the original questions were retained and added a few issues according to the European Quality Model (EFQM, 1996) and Norwegian characteristics. The final version covers the following criteria: quality leadership, human resource development, quality strategies, information resources, process and product, people satisfaction, participation of labour union, customer satisfaction, social and environmental impact, and the results. It was found that in Norwegian companies, implementation (or certification) of the 1509000 standards is significantly correlated with the results, especially in the reduction of bad products and customer complaints, business performance such as profitability and productivity, and the market position and competitiveness. However, the ISO9000 certificate has little influence on market position and competitiveness, and no influence on employee satisfaction and environmental protection. The standard may contribute directly to the results and may also indirectly contribute to the results by improving other TQM enablers. It seems that, in the future, the ISO9000 standards may be part of the TQM programme. This study also found that the number of years of practising quality management is significantly related in both the implementation TQM enablers and the results achieved from TQM and ISO9000 certification. Samson and Terziovski (1999) also analysed the possibility of the existence of a significant positive relationship between TQM elements and performance, in order to determine the relationship between TQM practices, individually and collectively, and company performance. The authors concluded that three elements of TQM, namely, leadership, customer focus and the focus on human resources had a significant positive effect. Moreover, as per Heras et al. (2002), good quality control is related to competitive advantage.

Heras et al. (2002) developed a comparative study of accredited and nonaccredited 400 companies by ISO9000. The results show an association between the ISO9000 certification and a superior financial performance. The implementation of any type of tool, system or program-related quality, tends to be amortized over 


\section{Intangible Capital}

Intangible Capital, 2010 - 6(2):258-271 - ISSN: 1697-9818 doi:10.3926/ic.2010.v6n2.p258-271

time. Achieving the benefits of a quality management system, ISO9000 certification is a process that takes time and is more likely to cause a rapid reversal in the business or financial results of the company. However, despite the fact that many companies have been certified for a short period, the study found statistically that there is a significant improvement in financial performance for certified firms in four of the five years studied. Thus, the research provides support for the discovery of Lloyd's Register of Quality Assurance Ltd (1996) and Häversjö (2000), in that certification of quality is linked with improved financial performance. Also Martínez-Lorente and Martínez-Costa (2004) examined whether there is a positive relationship measured independently between TQM implementation and business results and ISO9000 certification with the same, and when used in conjunction, ISO9000 certification and TQM, is there a positive relationship with business results. A total of 442 companies were analysed and data obtained show that TQM is positively related to operating results, whereas, the ISO9000 is not significantly related to the results. Together, the implementation of TQM and ISO9000 certification has a significant effect on results. However, when companies implement TQM and ISO9000 certification their average scores are higher. Also, per Corbett et al. (2005), not all companies will reap the benefits of ISO9000 certification; only companies that have implemented the standard more accurately obtain benefits. In general, the evidence collected from a study in the USA, supports the view that a careful design and an implementation that is consistent and well documented by a system of quality management contributes significantly to higher financial performance.

Feng, Terziovski and Samson (2008) tried to resolve the contradiction between some researchers who argue that the 1509000 certification prevents the development of innovation through the analysis of the impact of ISO 9000 certification in innovational performance conducted at a large number of Australian organizations. They concluded the ISO 9000 certification has had a significant negative effect on performance in product innovation, and a significant positive effect on performance and dimensions related to the innovation process. The results are consistent with previous studies. The implication for managers is that they need to exercise care in selecting the appropriate procedures for certification.

In 2009, Martínez-Lorente et al. compared the implementation of ISO9000/1994 and ISO9001/2000 as representatives of two efforts to implement practices of quality management. They evaluated the impact on business performance for a 


\section{- Intangible Capital}

Intangible Capital, 2010 - 6(2):258-271 - ISSN: 1697-9818

doi:10.3926/ic.2010.v6n2.p258-271

sample of 713 Spanish industrial companies and also analysed whether the 2000 version of ISO is more similar to the implementation of TQM. They concluded that the companies certified with ISO 9001/2000 have noticeably better performance than companies certified by ISO9000/1994 or uncertified firms. However, the authors found that the ISO 9001/2000 certified companies apply a much higher level of TQM than the firms certified by ISO9000/1994, but they have a less clear position on increased performance.

\section{Conclusions}

The aim of this work was to do a literature review on some of the many published studies, which seek to analyse the relationship between the implementation of systems of quality management, ISO9000 certification, quality costs, results and business performance.

The ISO9000 family of standards are benchmarks for the implementation of systems of quality management, which represent an international consensus on good management practices with the aim of ensuring the supply of products that meet customer requirements and focus on continuous improvement. They are also a basis for the design, implementation, evaluation, specification and certification of quality systems, introducing a common language internationally. It is also now an essential requirement for a company to stay on the market. Thus, this study concluded that:

- One of the benefits attributed to ISO9000, is that constitutes a good first step in the direction of a TQM system, thus creating a climate of change in the way of running the company.

- The version of ISO in the year 2000 introduced some key aspects of quality in the previous version (1994), such as continuous improvement and customer orientation, which are two aspects of great importance, and without them the companies implemented a quality management at a superficial level.

- The ISO9000 and TQM have points in common, yet one of the most important reasons for obtaining ISO9000 certification are the external reasons, i.e, companies tend to do so by pressure from customers and suppliers, or for marketing reasons. 


\section{- Intangible Capital}

Intangible Capital, 2010 - 6(2):258-271 - ISSN: 1697-9818

doi:10.3926/ic.2010.v6n2.p258-271

- Companies often are too anxious to get certified and tend to neglect what should be the main reason to obtain the certification, that is, a better system of quality management.

- The time and cost to implement TQM can vary between companies, and the size of the potential gain from TQM implementation can be affected by the company's technology. As well, the synergies in the implementation of TQM may depend on the various markets in which firms operate. Any type of tool, system or program-related quality tends to be amortized over time.

- The ISO9000 certification process represents an evolution in how a company and quality system needs to be monitored and may be the key to successful business management. The consistent implementation of a system of quality management contributes significantly to a better financial performance. The way the company implements the standard is what distinguishes a business from others in performance. The better the company uses the standard in their daily operational practices, the greater the performance.

- The ISO9000 standards assume an evolution in how to manage a company, organization, communication and quality system, which in general are the key to success in business management, where the aim of continuous improvement becomes a basic tool to advance the competitiveness of business.

- The standard can contribute directly or indirectly in the results, by improving the TQM enablers. However, the results of certification depend on the type of motivation and why companies decide to certify.

\section{References}

ASKEY, J.M.; DALE, B.G. (1994). From ISO9000 series registration to Total Quality Management: An examination. Quality Management Journal, July: 67-76.

BENNER, M.J .; VELOSO, F.M. (2008). ISO9000 practices and financial performance: a technology coherence perspective. Journal of Operations Management, 26: 611629. doi: 10.1016/j.jom.2007.10.005 


\section{- Intangible Capital}

Intangible Capital, 2010 - 6(2):258-271 - ISSN: 1697-9818

doi: 10.3926/ic.2010.v6n2.p258-271

BOIRAL, O.; AMARA, N. (2009). Paradoxes of ISO9000 performance: A configurational Approach. Quality Management Journal, 16(3): 37-60.

BHUIYAN, N.; ALAM, N. (2004). ISO9001:2000 implementation-The North American experience. International Journal of Productivity and Performance Management, 53, ABI/INFORME Global: 10-17.

CASADÉSUS, M.; GIMÉNEZ, G. (2000). The benefits of the implementation of the ISO9000 standard: Empirical research in 288 Spanish companies. The TQM Magazine, 12(6): 432-41. doi: 10.1108/09544780010351751

CORBETT, C.; MONTES-SANCHO, M.J.; KIRSCH, D.A. (2005). The financial impact of ISO9000 certification in the United States: An empirical analysis. Management Sciences, 51(7): 1046-1059. doi: 10.1287/mnsc.1040.0358

EASTON, G.S.; JARRELL, S.L. (1998). The effects of Total Quality Management on corporate performance: An empirical Investigation. Journal of Business, 71(2): 253-307. doi: 10.1086/209744

EBRAHIMPOUR, M.; WITHERS, B.E.; HIKMET, N. (1997). Experiences of US and Foreign-Owned Firms: A new perspective on ISO9000 Implementation. International J ournal of Production Research, 37(2): 567-576.

EREL, E.; GHOSH, G.B. (1997). ISO9000 implementation in Turkish industry International. Journal of Operations and Production Management, 17(12): 12331246. doi: $10.1108 / 01443579710182972$

ESCANCIANO, C.; FERNÁNDEZ, E.; VÁZQUEZ, C. (2001). ISO 9000 certification and quality management in Spain: results of a national survey. The TQM Magazine, 13(3): 192-200. doi: 10.1108/09544780110385500

ESCANCIANO, C. (2002). Certificación ISO9000 en España: Dificultades versus satisfacción empresarial. Dirección y Organización, 27: 148-156.

FENG, M.; TERZIOVSKI, M.; SAMSON, D. (2008). Relationship of ISO9001-2000 quality systems certification with operational and business performance. Journal of Manufacturing Technology Management, 19(1): 2237. doi: $10.1108 / 17410380810843435$ 


\section{- Intangible Capital}

Intangible Capital, 2010 - 6(2):258-271 - ISSN: 1697-9818

doi:10.3926/ic.2010.v6n2.p258-271

FUENTES, M.M. (2002). La estructura sectorial y la gestión de la calidad total. Impacto en el resultado de las empresas. Economía Industrial, 345: 135-146.

HÄVERSJÖ, T. (2000). The financial effects of ISO9000 registration for Danish companies. Managerial Auditing Journal, 15 (1/2): 4752. doi: $10.1108 / 02686900010304632$

HENDRICKS, K.B.; SINGHAL, V.R. (2001). Firm Characteristics, total quality management and financial performance. Journal of Operations Management, 19: 269-285. doi: 10.1016/50272-6963(00)00049-8

HERAS, I.; CASADESÚS, M.; GARVIN, P.M. (2002). ISO9000 Certification and the bottom line: A comparative study of the profitability of basque region companies. Managerial Auditing J ournal, 17(1/2): 72-78. doi: 10.1108/02686900210412270

ITTNER, D.; LARCKER, D. (1997). Quality Strategy, strategic control systems, and organizational performance. Accounting Organizations and Society, 22 (3/4): 293314. doi: 10.1016/S0361-3682(96)00035-9

ISO SURVEY (2008). www.iso.org [Consulted: 05/01/2010].

LLOYD'S REGISTER OF QUALITY ASSURANCE LTD (1996). Fitter Finance. The effects of ISO9000 on business performance. Report survey findings. Lloyd's, London.

LIMA, M.A.M.; RESENDE, M.; HASENCLEVER, L. (2000). Quality certification and performance of Brazilian firms: An empirical study. International Journal of Production Economics, 66: 143-147. doi: 10.1016/S0925-5273(99)00118-8

MARTÍNEZ-COSTA, M.; MARTíNEZ-LORENT, A.R. (2004). Sistemas de gestión de calidad y resultados empresariales: Una justificación desde las teorias institucional y de recursos y capacidades. Cuadernos de Economia y Dirección de la Empresa, 34: 7-30.

MARTÍNEZ-COSTA, M.; CHOI, T.; MARTÍNEZ, J.; MARTÍNEZ-LORENTE, A. (2009). ISO9000/1994, ISO9001/2000 and TQM: The performance debate revisited. Journal of Operations Management, 27: 495-511. doi: 10.1016/j.jom.2009.04.002

MARTÍNEZ-LORENTE, A.R.; MARTÍNEZ-COSTA, M. (2004). ISO9000 and TQM: Substitutes or complementaries? An empirical study in industrial companies. 


\section{- Intangible Capital}

Intangible Capital, 2010 - 6(2):258-271 - ISSN: 1697-9818 doi:10.3926/ic.2010.v6n2.p258-271

International Journal of Quality and Reliability Management, 21(3): 260276. doi: $10.1108 / 02656710410522711$

MOLINA, L.M.; LLORÉNS-MONTES, J.; RUIZ-MORENO, A. (2007). Relationship between quality management practices and knowledge transfer. Journal of Operations Management, 25: 682-701. doi: 10.1016/j.jom.2006.04.007

NAVEH, E.; MARCUS, A. (2005). Achieving competitive advantage through implementing a replicable management standard: installing and using ISO9000. J ournal of Operations Management, 24: 1-26. doi: 10.1016/j.jom.2005.01.004

PETERAF, M.A. (1993). The cornerstones of competitive advantage: a resource based view. Strategic Management Journal, 14: 179192. doi: $10.1002 / \mathrm{smj} .4250140303$

ROMANO, P. (2000). ISO9000: What is its impact on performance? Quality Management J ournal, 7(3): 38-56.

SAMSON, D.; TERZIOSVKI, M. (1999). The relationship between total quality management practices and operational performance. Journal of Operations Management, 17: 393-409. doi: 10.1016/S0272-6963(98)00046-1

SANSALVADOR, M.E.; CAVER RUBIO, J. (2005). El coste total de la calidad en organizaciones ISO9000: Un estudio empírico. Revista Española de Financiación y Contabilidad, XXXIV(127): 899-924.

SUN, H. (1999). Diffusion and contribution of total quality management: An empirical study in Norway. Total Quality Management, 6(6): 901-914.

SUN, H. (2000). TQM, ISO9000 Certification and performance improvement. International Journal of Quality \& Reliability Management, 17(2): 1027. doi: $10.1108 / 02656710010304573$

TERZIOVSKI, M.; SAMSON, D. (1997). The business value of quality management systems certification: Evidence from Australia and New Zealand. Journal of Operations Management, 15: 1-18. doi: 10.1016/S0272-6963(96)00103-9

TEXEIRA, J.; ALMAÇA, J.; JUSTINO, M.R. (2009). Certificação de Qualidade versus Resultado da Empresa: Evidência empirica. XIX Jornadas Hispano Lusas de Gestión Científica. Universidad de Jaén. Baeza. ISBN: 978-84-691-8776-0. 


\section{- Intangible Capital}

Intangible Capital, 2010 - 6(2):258-271 - ISSN: 1697-9818

doi:10.3926/ic.2010.v6n2.p258-271

TEXEIRA, J.; JUSTINO, M.R. (2009). Certification of Quality Management Systems under ISO9000 versus business bottom line: empirical evidence. XXIII Congreso Anual AEDEM (La Academia Europea de Dirección y Economía de la Empresa). Sevilla. ISBN: 978-84-7356-609-4.

VLOEBERGHS, D.; BELLENS, J. (1996). Implementing the ISO9000 standards. Quality Progress, 29(6): 46-48.

TSIOTRAS, G.; GOTZAMANI, K. (1996). ISO9000 as an entry key to TQM: The case of Greek industry. International J ournal of Quality, 13(4): 64-76.

YAMADA, S. (2001). Economical aspects of ISO9000 certification in Japonese Companies. AQC Annual Quality Congress, Charlotte, NC. 55 (0), 647-659.

YOUNGDAHL, W.; KELLOGG, D. (1997). The relationship between service customers quality assurance behaviors, satisfaction, and effort: A cost of quality perspective. Journal of Operations Management, 15: 19-32. doi:10.1016/S0272$\underline{6963(96) 00097-6}$

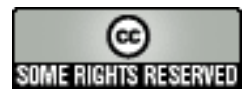

Article's contents are provided on a Attribution-Non Commercial 3.0 Creative commons license. Readers are allowed to copy, distribute and communicate article's contents, provided the author's and Intangible Capital journal's names are included. It must not be used for commercial purposes. To see the complete license contents, please visit http://creativecommons.org/licenses/by-nc/3.0/es/ 